
НАПРЯМИ ПІДВИЩЕННЯ ЕФЕКТИВНОСТІ УПРАВЛІННЯ РЕНТАБЕЛЬНІСТЮ
ПІДПРИЄМСТВА (НА ПРИКЛАДІ ПІДПРИЄМСТВ ТОРГІВЛІ)

\title{
WAYS TO IMPROVE THE MANAGEMENT EFFICIENCY OF ENTERPRISE PROFITABILITY (THE CASE OF TRADE ENTERPRISES)
}

\begin{abstract}
У статті проаналізовано стан управління рентабельністю вітчизняних підприємств, у тому числі особливу увагу було приділено підприємствам сорери оптової та роздрібної торгівлі. Встановлено, що управління рентабельністю вітчизняних підприємств сорери торгівлі поступово відновлюється, проте не позбавлене численних проблем. Узагальнено інформацію щодо можливих напрямів удосконалення системи управління рентабельністю вітчизняного бізнесу. Встановлено, що загальною проблемою системи дослідження фракторного впливу на рентабельність діяльності підприємства $\epsilon$ недостатня оцінка сили такого впливу. На основі використання кореляційно-регресійного аналізу запропоновано фракторну модель оцінки впливу на операційну рентабельність діяльності підприємств торгівлі таких чинників, як рівень ліквідності та платоспроможності, фрінансової стійкості та ділової активності. Встановлено, що найсильніший вплив має рівень їхньої ліквідності та платоспроможності.

Ключові слова: рентабельність, прибутковість, прибуток, підприємство, управління, фрактор.
\end{abstract}

В статье проанализировано состояние управления рентабельностью отече- ственных предприятий, в том числе особое внимание было уделено предприятиям ссреры оптовой и розничной торговли. Установлено, что управление рентабельностью отечественных предприятий сфреры торговли постепенно восстанавливается, однако не лишено многочисленных проблем. Обобщена информация о возможных направлениях совершенствования системы управления рентабельностью отечественного бизнеса. Установлено, что общей проблемой системы исследования факторного влияния на рентабельность деятельности предприятия является недостаточная оценка силы такого воздействия. На основе использования корреляционно-регрессионного анализа предложена фракторная модель оценки влияния на операционную рентабельность деятельности предприятий торговли таких фракторов, как уровень ликвидности и платежеспособности, фринансовой устойчивости и деловой активности. Установлено, что наиболее сильное влияние осуществляет уровень их ликвидности и платежеспособности.

Ключевые слова: рентабельность, доходность, прибыль, предприятие, управление, фрактор.

The article substantiates the idea of an irregularity of the research problems of increasing the efficiency of management of profitability of domestic enterprises. The present state of management of profitability of domestic enterprises, including special attention was paid to the enterprises of the sphere of wholesale and retail trade, was analyzed. It is established that the management of profitability of domestic enterprises of the trade sphere is gradually restored, but not without numerous problems. The information on possible directions of improvement of the management system of profitability of domestic business is generalized. It is established that the general problem of the system of research of factor influence on profitability of enterprise activity is insufficient estimation of force of such influence. Based on the use of correlation-regression analysis, a factor model for assessing the impact on operating profitability of trading enterprises of such factors as liquidity and solvency, financial sustainability and business activity is proposed. It was found that the strongest influence is on their level of liquidity and solvency. It is established that significant effect on the researched result indicator is also made by the ratio of receivables and payables and turnover of working capital of the enterprise. However, it is worrying that, in accordance with the model for increasing the profitability of the operating activities of the enterprise, it is necessary to increase the amount of receivables in comparison with the amount of payables and, conversely, reduce the turnover of working capital. Regardless of the results of correlation-regression analysis, in our opinion, from an economic point of view, the reduction of debt ratios would be more correct if growth of working capital turnover was increasing. Accordingly, we can state that this problem has the right to life, but requires a more thorough analysis using statistical data over a longer period, as well as with a diversification of factor indicators, including through the use of factors characterizing the influence of the environment on the enterprises of the sphere trade.

Key words: profitability, profitability, profit, enterprise, management, factor.

Постановка проблеми. Тривалий час отримання прибутку підприємством вважалося найголовнішим його завданням. Натомість сьогодні проблеми управління прибутком та рентабельністю підприємства нібито відходять на другий план, пропускаючи вперед необхідність забезпечення довгострокового існування підприємства, забезпечення й утримання конкурентних переваг, ринкову капіталізацію підприємства. Насправді досягнення жодного 3 перелічених завдань неможливе без ефективного управління не тільки формуванням й розподілом прибутку, але й рентабельністю (прибутковістю) діяльності підприємства загалом чи здійснення окремих його функцій.
Аналіз останніх досліджень і публікацій. Окремі проблемні питання управління рентабельністю як зарубіжних, так і вітчизняних підприємств досліджували такі автори, як Т. Архіпова, М. Баканов, Л. Бернстайн, М. Білик, Е. Колосов, В. Колотович, О. Кононенко, М. Коробов, Я. Костецький, В. Крініцин, Є. Мних, Ю. Прохоров, Е. Руда, Г. Савицька, Е. Смирнов, С. Фішер, В. Фролов, Дж. Ван Хорн, О. Шеремет, Ю. Цал-Цалко та багато інших.

Однак специфріка фрункціонування вітчизняного бізнесу в сьогоднішніх доволі непередбачуваних і динамічних умовах потребує не тільки ретельного аналізу змін, що відбуваються в галузі управління рентабельністю підприємств, але і своєчасного 
й доволі інноваційного реагування на відповідні виклики внутрішнього та зовнішнього середовищ підприємства.

Постановка завдання. У зв'язку з цим метою статті $€$ дослідження сучасного стану управління рентабельністю підприємств торгівлі й визначення можливих напрямів його покращення.

Виклад основного матеріалу дослідження. У сучасному фраховому просторі проблемі аналізу стану рентабельності окремих підприємств, окремих галузей і економіки загалом присвячено чимало праць [1-5; 15; 16], з яких видно, що ця проблема $€$ актуальною, а її значення для структурного оновлення всієї економічної системи країни тільки зростає.

Так, І.А. Бержанір відзначає, що загальний рівень рентабельності суб'єктів господарювання за 2008-2013 рр. знижувався в середньому на 7,3\% щорічно і на кінець 2013 р. становив лише 4,1\%. Причому найбільш ефективно 3 погляду генерування прибутку спрацювали підприємства сорер сільського господарства і транспорту та зв'язку [1, с. 27].

В одному з наших попередніх досліджень ми також досліджували стан рентабельності операційної діяльності великих та середніх підприємств за видами економічної діяльності з 2010 по вересень 2017 р. [2]. І нами було встановлено, що, з одного боку, простежується зростання рівня рентабельності профресійної, наукової та технічної діяльності, а також промисловості загалом, що має створювати підґрунтя для розбудови всієї економічної системи країни, а 3 іншого - динаміка й рівень змін рентабельності за окремими галузями економіки $€$ доволі нестабільними, а високий рівень варіативності отриманих значень свідчить про високий рівень ризику та відповідно низький рівень інвестиційної привабливості країни загалом.

У цьому дослідженні ми свою увагу ми зосередимо на підприємствах оптової та роздрібної торгівлі, оскільки в умовах практично тотального знищення промислового виробництва та так званих «ринкових перетворень» саме в цій сорері зайнято чи не найбільше людей. Так, на кінець 2017 року з 8271,3 тис. осіб, зайнятих в усій економіці, 2223,1 тис. осіб (26,88\%) зайнято у сорері, яка має назву «оптова та роздрібна торгівля; ремонт автотранспортних засобів і мотоциклів». Більше зайнято лише в промисловості - 2334,2 тис. осіб $(28,22 \%)[6]$.

Звичайно, цей сектор економіки важко назвати «фрлагманом» чи «драйвером» економіки, проте, зважаючи на соціальну роль цих підприємств у забезпеченні добробуту населення країни, він $€$ одним із доволі важливих і таких, що потребують значної уваги до забезпечення сталості його діяльності.
Проведений К. А. Дєнєжко та Ю. П. Жиліною аналіз показав, що за 2010-2012 рр. підприємства роздрібної торгівлі були збитковими, але збитковість у динаміці спочатку знизилась на 85,07\%, а в 2012 зросла в 4,6 разу. Ними також було виявлено, що показники чистого збитку підприємств роздрібної торгівлі знижуються більш повільними темпами, ніж показники збитку від їхньої звичайної діяльності до оподатковування [3, с. 60], що є доволі незвичайним явищем.

Від себе можемо додати, що, незважаючи на тривалий період збиткової діяльності, вже в 2018 році підприємства цього сектору економіки почувалися значно краще, сукупний обсяг їх чистого прибутку становив 70556,2 млн. грн. У січні-березні 2019 року обсяг чистого прибутку становив 12134,8 млн. грн., це забезпечило підприємствам цієї сорери діяльності рентабельність операційної діяльності на рівні $24 \%$, що на відповідний період часу поступається лише підприємствам, зайнятим операціями з нерухомим майном (39,8\%) та інорормацією і телекомунікаціями (24,3\%). При цьому традиційно найвищий рівень рентабельності демонструють середні підприємства, далі йдуть великі, малі і мікропідприємства, тоді як у більшості задекларованих стратегічних орієнтирів нашої країни малому бізнесу відводиться найбільша роль в покращенні економічного стану країни.

Відповідно, очевидним є фракт того, що процес управління рентабельністю вітчизняних підприємств, у тому числі в сфрері торгівлі, потребує негайного удосконалення.

Важливо відзначити, що і в цьому напрямі можна знайти чимало робіт, завданнями яких $\epsilon$ підвищення рентабельності чи просто збільшення прибутку підприємств. Проте поради щодо покращення рентабельності вітчизняного бізнесу найчастіше лежать на поверхні і стосуються зростання обсягів виробництва та реалізації продукції підприємства, зростання цін, зниження собівартості, оновлення асортименту й номенклатури продукції, що випускається [7, с. 69; 8, с. 41; 9, с. 228], впровадження економічно обґрунтованих норм на підприємстві, досягнень науково-технічного прогресу, підвищення якості продукції, що реалізується, та продуктивності праці, використання вторинних ресурсів та попутних продуктів, правильного та економічно обґрунтованого вибору маркетингової політики підприємства [10, с. 93].

Деякі автори звертають увагу на «підвищення конкурентоспроможності власної продукції за рахунок зменшення частки пасивних фрондів у загальній вартості основних фрондів та зменшення адміністративно-управлінських витрат», «поліпшення ефективності управління, підвищення прибутковості праці, ефективності виробництва», а також вважають, що «найбільший ефект підви- 
щення рентабельності досягається за пошуку резервів на передвиробничій стадії» [11, с. 107].

У деяких дослідженнях, наприклад у роботі К.Г. Міщенко, пропонується розподіляти фрактори на внутрішні (обсяг діяльності підприємства, стан та ефективність використання ресурсів підприємства, рівень доходів, рівень витрат, ефективність цінової та асортиментної політики) і зовнішні (державне регулювання цін в сучасних умовах на товари, які входять до споживчого кошика, подорожчання послуг інших галузей народного господарства, система оподаткування, зміна нормативних документів 3 кредитування, збільшення облікової ставки за користування кредитними, політика держави по фрормуванню доходів, відсутність індексації доходів населення залежно від темпів інсрляції) [11, с. 106].

В інших же дослідженнях до вирішення цієї проблеми (проблеми визначення напрямів удосконалення системи управління рентабельністю підприємств) підходять більш ґрунтовно і виділяють такі глобальні фрактори впливу, як технологія, устаткування, матеріали та енергія, вироби, працівники, організація і системи, методи роботи, стиль управління, державна економічна і соціальна політика, інституціональні механізми, інфраструктура, структурні зміни в суспільстві [12, с. 157-160].

Насправді, на нашу думку, всі ці дослідження мають право на існування й дають нам узагальнення бачення того, що врешті-решт впливає на прибуток та рентабельність діяльності підприємства. Проте жодне дослідження не визначає, що на вирішення всіх цих питань одночасно у підприємств не вистачає не тільки фонансових, але й часових, людських, організаційних ресурсів. Добре, що ми знаємо, в якому напрямі потрібно рухатись, але погано, що ми не знаємо, на який результат можна очікувати від реалізації тих чи інших заходів, тобто невідома вагомість вирішення тих чи інших проблем.

Вирішенню відповідних завдань сприяє проведення фракторного аналізу, який, крім загального декларування наявності впливу окремих фракторів, дає нам розуміння ще й сили цього впливу.

Стосовно фракторного впливу на показники рентабельності застосовується ціла низка методів, зокрема, різні варіації методу компанії DuPont [4; 13] модель М.І. Баканова й А.Д. Шеремета [14], побудови регресійних моделей [5] тощо.

Не применшуючи значення й вагомість тієї чи іншої моделі, необхідно відзначити, що вони охоплюють вплив не всіх фракторів, вплив яких нам цікавий. Відповідно, авторами цієї роботи також було поставлено на меті розроблення власної факторної моделі, побудованої на дослідженні наявних статистичних даних із використанням механізмів кореляційно-регресійного аналізу.

Стосовно ж логіки вибору результуючого показника, яким нами було вибрано рентабель- ність операційної діяльності, необхідно відзначити, що вона продиктована як об'єктивними, так і суб'єктивними фракторами. Так, з одного боку, це лише один з показників рентабельності, який $є$ в вільному доступі й відображений на сайті Державної служби статистики України, а з іншого - саме операційна діяльність характеризує успішність підприємства, оскільки вона $є$ основною й тієї, заради якої створювалося саме підприємство.

Відповідно, вибір фракторних показників зумовлений бажанням охопити всі внутрішні сторони діяльності підприємства, які в сукупності характеризують його фрінансовий стан. Ліквідність та платоспроможність характеризує співвідношення коефіцієнта покриття та його нормативу (зважаючи на різноманіття підходів до вибору нормативного значення цього коефіцієнта, ми зупинилися на значенні «2»). Фінансову стійкість - коефіцієнт автономії та співвідношення дебіторської та кредиторської заборгованостей. Ділову активність характеризують показники оборотності сукупного й власного капіталу (табл. 1).

Використавши можливості вкладки «Аналіз даних» табличного редактора Excel, було сорормовано таку економіко-математичну модель:

$$
\begin{aligned}
& P=469,42+250,66 Д К 3+13,95 К А ~+ \\
& +57,32 \mathrm{OK}-2,010 \mathrm{OKK}-1486,59 \mathrm{~K}
\end{aligned}
$$

Найбільший вплив на операційну рентабельність діяльності підприємства чинять такі фрактори, як платоспроможність та ліквідність і співвідношення заборгованостей підприємства. Натомість оборотність власного капіталу $є$ найменш впливовим 3 усіх фракторів.

Про достовірність отриманих результатів свідчить той фракт, що коефіцієнт множинної кореляції становить 0,9254, а коефріцієнт детермінації $\mathrm{R}^{2}=0,8563$, тобто отримана модель описує 85,63\% фракторних змін, що свідчить про задовільну апроксимацію.

При цьому достовірність за рівнем значущості критерію Фішера (Значимість F) значно більша за 0,05, відповідно, модель $€$ незначущою. I насправді отримані результати $€$ досить таки несподіваними. Так, відповідно до наведеної моделі, для зростання рентабельності потрібно нарощувати співвідношення дебіторської й кредиторської заборгованостей і зменшувати співвідношення коефіцієнта покриття та його нормативу.

Відповідно, 3 метою підвищення рівня значущості розробленої моделі здійснимо додатковий відбір змінних з допомогою методу прямого відбору (Forward Selection) і попереднього кореляційного аналізу (табл. 2).

Як бачимо, найбільш тісний зв'язок простежується 3 таким фрактором, як «оборотність сукупного капіталу». Тому саме ця змінна повинна бути першою піддана процедурі перевірки на вклю- 
Вихідна інформація для проведення аналізу факторного впливу на рентабельність операційної діяльності вітчизняних підприємств

\begin{tabular}{|l|c|c|c|c|c|c|}
\hline & $\mathbf{2 0 1 2}$ & $\mathbf{2 0 1 3}$ & $\mathbf{2 0 1 4}$ & $\mathbf{2 0 1 5}$ & $\mathbf{2 0 1 6}$ & $\mathbf{2 0 1 7}$ \\
\hline Рентабельність операційної діяльності (Р), \% & 12,2 & 10,2 & $-12,8$ & $-0,9$ & 15,8 & 18,8 \\
\hline $\begin{array}{l}\text { Співвідношення дебіторської і кредиторської } \\
\text { заборгованостей (ДКЗ) }\end{array}$ & 0,768 & 0,772 & 0,994 & 1,027 & 1,254 & 1,127 \\
\hline Коефіцієнт автономії (КА), \% & 9,571 & 8,494 & $-2,050$ & $-4,816$ & $-4,475$ & 0,105 \\
\hline $\begin{array}{l}\text { Оборотність сукупного капіталу (ОК), } \\
\text { обертів на рік }\end{array}$ & 0,503 & 0,412 & 0,750 & 0,777 & 0,342 & 0,352 \\
\hline $\begin{array}{l}\text { Оборотність власного капіталу (ОВК), } \\
\text { обертів на рік }\end{array}$ & 2,510 & 2,237 & 11,585 & $-10,871$ & $-5,347$ & $-17,974$ \\
\hline $\begin{array}{l}\text { Співвідношення фрактичного розміру й } \\
\text { нормативу коесріцієнта покриття (КП), \% }\end{array}$ & 0,539 & 0,527 & 0,486 & 0,489 & 0,495 & 0,532 \\
\hline
\end{tabular}

Джерело: розраховано авторами на основі даних [6]

Результати кореляційного аналізу рівня рентабельності

Таблиця 2 операційної діяльності з вибраними змінними

\begin{tabular}{|c|c|c|c|c|c|c|}
\hline & P & ДК3 & KA & OK & OBK & Kп \\
\hline P & 1 & & & & & \\
\hline ДК3 & 0,149247 & 1 & & & & \\
\hline KА & 0,305552 & $-0,86535$ & 1 & & & \\
\hline OK & $-0,90947$ & $-0,17099$ & $-0,32565$ & 1 & & 1 \\
\hline OBK & $-0,6$ & $-0,51434$ & 0,337107 & 0,348152 & $-0,18212$ & 1 \\
\hline KП & 0,684886 & $-0,51922$ & 0,831552 & $-0,6135$ & - \\
\hline
\end{tabular}

чення в модель. Знайдемо оцінки значень результуючого ознаки, отримані на підставі моделі, яка включає тільки одну незалежну змінну ОК. Отримали такі значення: $\mathrm{R}^{2}=0,82714$, Fроз $=23,93$, Fкрит $=5,99$, тобто виконується умова значущості критерію Fроз > Fкрит. При цьому достовірність за рівнем значущості критерію Фішера (Значимість F) достатня, а отже, змінна ОК має бути включена до моделі.

Провівши декілька ітерацій, нами було знайдено модель, яка була б достовірно значущою:

$$
\mathrm{P}=-138,73+21,49 \text { ДКЗ - 31,12 ОК + 275,72КП (2) }
$$

Отримали такі значення: $\mathrm{R}^{2}=0,89511$, Fpoз = 17,07, Fкрит $=4,76$, тобто виконується умова значущості критерію नроз > Fкрит.

Висновки 3 проведеного дослідження. Таким чином, підсумовуючи результати цього дослідження, необхідно відзначити, що на рентабельність операційної діяльності підприємств торгівлі найбільш сильно впливають ліквідність і платоспроможність. Значний вплив на досліджуваний результуючий показник здійснюють також співвідношення дебіторської та кредиторської заборгованостей та оборотність обігових коштів підприємства.

Однак викликає занепокоєння той факт, що відповідно до отриманої моделі для збільшення рентабельності операційної діяльності підприємства необхідно нарощувати обсяги дебі- торської заборгованості порівняно $з$ обсягами кредиторської заборгованості та, навпаки, скорочувати оборотність обігових коштів. Незважаючи на результати кореляційно-регресійного аналізу, на нашу думку, з економічного погляду більш коректним було би скорочення співвідношення заборгованостей за зростання оборотності обігових коштів. Відповідно, можемо констатувати, що ця проблематика має право на життя, але потребує більш досконалого аналізу з використанням статистичних даних за більш тривалий період, а також 3 урізноманітненням фракторних показників, у тому числі за рахунок використання фракторів, що характеризують силу впливу зовнішнього середовища на підприємства сорери торгівлі.

\section{БІБЛІОГРАФІЧНИЙ СПИСОК:}

1. Бержанір І.А. Діагностика рентабельності суб'єктів господарювання України. Економіка $і$ організація управління. 2014. № 3(19)-4(20). С. 25-29.

2. Чемчикаленко Р.А., Майборода О.В., Сокольченко В.І. Рентабельність діяльності вітчизняних підприємств: оцінка сучасного стану. Глобальні та національні проблеми економіки. 2018. Випуск № 23. С. 579-584.

3. Дєнєжко К. А., Жиліна Ю. П. Аналіз підвищення рентабельності підприємств роздрібної торгівлі в Україні. Управління розвитком. 2014. № 4 (167). С. 59-61. 
4. Костецький Я. Факторний аналіз рентабельності діяльності сільськогосподарських підприємств. Економічний аналіз. 2012. Випуск 10. Частина 4. С. 179-181.

5. Проскурович О. В., Басс А. Ю. Моделювання рентабельності діяльності підприємства. Вісник Хмельницького національного університету. 2015. № 3. T. 3. С. 209-212.

6. Документи Державної служби статистики України. Київ, 2019. URL: http://ukrstat.org/uk/operativ/ menu/menu_u/sze.htm (дата звернення: 10.07.2019).

7. Лойко В.В., Несенюк Є. С. Шляхи збільшення обсягу прибутку та підвищення дієвості управління прибутком промислового підприємства в сучасних умовах господарювання. Международный научный журнал. 2015. № 7. С. 68-71.

8. Кучерява А.С. Прибутковість підприємства та шляхи її підвищення. Проблеми підвищення ефективності інфрраструктури. 2015. № 40. С. 38-44.

9. Приймук О., Салієнко О. Діагностика фрінансового стану та підвищення рентабельності підприємства. Збірник наукових праць ДЕТУТ. Серія «Економіка і управління». 2016. Вип. 36. С. 223-230.

10. Мелень О.В., Гарібян Т.А. Актуальність питань розробки напрямів підвищення прибутковості підприємства. Науковий вісник Херсонського державного університету. 2014. Випуск 8. Частина 3. С. 91-94.

11. Міщенко К. Г. Прибутковість підприємства та шляхи її підвищення. Международный научный журнал «Интернаука». 2017. № 2 (24). С. 105-107.

12. Болюх М.А., Бурачеський В.3. Економічний аналіз. Київ. 2011. 540 с.

13. Ступницька Т.М., Гула О.С. Аналіз фракторів, що впливають на зміну рентабельності основного капіталу, за методом корпорації «Дюпон». Економіка харчової промисловості. 2013. № 3(19). С. 21-23.

14. Семенова О. М., Середа І. В. Резерви підвищення рентабельності підприємства на основі фракторного моделювання. Науковий вісник Полтавського університету економіки і торгівлі. 2014. № 1 (63). C. 162-167.

15. Свірідова С.С., Пожар О.О. Оцінка фракторів впливу на рентабельність підприємства. Молодий вчений. 2014. № 11 (14). С. 93-96.

16. Фаріон В.Я. Аналітична оцінка ділової активності та рентабельності підприємств. Інноваційна економіка. 2013. № 10(48). С. 27-33.

\section{REFERENCES:}

1. Berzhanir I.A. (2014) Diahnostyka rentabelnosti subiektiv hospodariuvannia Ukrainy [Diagnostics of profitability of business entities of Ukraine]. Economics and management organization. vol. 3-4, no. 19-20, pp. 25-29.

2. Chemchykalenko R.A., Maiboroda O.V., Sokolchenko V.I. (2018) Rentabelnist diialnosti vitchyznianykh pidpryiemstv: otsinka suchasnoho stanu [Profitability of domestic enterprises: assessment of the current state]. Global and national problems of the economy. vol. 23. pp. 579-584.

3. Dieniezhko K. A., Zhylina Yu. P. (2014) Analiz pidvyshchennia rentabelnosti pidpryiemstv rozdribnoi torhivli $v$ Ukraini [Analysis of increase of profitability of retail enterprises in Ukraine]. Development management. vol. 4, no. 67. pp. 59-61.

4. Kostetskyi Ya. (2012) Faktornyi analiz rentabelnosti diialnosti silskohospodarskykh pidpryiemstv [Factor analysis of profitability of agricultural enterprises]. Economic analysis. vol. 10. part 4. pp. 179-181.

5. Proskurovych O. V., Bass A. Yu. (2015) Modeliuvannia rentabelnosti diialnosti pidpryiemstva [Modeling profitability of the enterprise]. Bulletin of the Khmelnytsky National University. vol. 3. pp. 209-212.

6. Publikatsiia dokumentiv Derzhavnoi Sluzhby Statystyky Ukrainy [Publication of documents of the State Service of Statistics of Ukraine]. Available at: http://ukrstat.org/uk/operativ/oper_new.html (accessed 10 July 2019).

7. Loiko V.V., Neseniuk Ye. S. (2015) Shliakhy zbilshennia obsiahu prybutku ta pidvyshchennia diievosti upravlinnia prybutkom promyslovoho pidpryiemstva v suchasnykh umovakh hospodariuvannia [Ways to increase the profit and increase the efficiency of management of profits of an industrial enterprise in modern economic conditions]. International Scientific Journal. vol. 7. pp. 68-71.

8. Kucheriava A.S. (2015) Prybutkovist pidpryiemstva ta shliakhy yii pidvyshchennia [Profitability of the enterprise and ways of its increase]. Problems of improving the efficiency of the infrastructure. vol. 40. pp. 38-44.

9. Pryimuk O., Saliienko O. (2016) Diahnostyka finansovoho stanu ta pidvyshchennia rentabelnosti pidpryiemstva [Diagnostics of financial condition and increase of profitability of the enterprise]. Collection of scientific works DETUT. Series "Economics and Management". vol. 36. pp. 223-230.

10. Melen O.V., Haribian T.A. (2014) Aktualnist pytan rozrobky napriamiv pidvyshchennia prybutkovosti pidpryiemstva [Actuality of issues of development of directions of increasing profitability of the enterprise]. Scientific Herald of Kherson State University. vol. part 3. pp. 91-94.

11. Mishchenko K. H. (2017) Prybutkovist pidpryiemstva ta shliakhy yii pidvyshchennia [Profitability of the enterprise and ways of its increase]. International scientific magazine "Internauca". vol. 2, no. 24. pp. 105-107.

12. Boliukh M.A., Buracheskyi V.Z. (2011) Ekonomichnyi analiz [Economic analysis]. Kiev. (in Ukrainian)

13. Stupnytska T.M., Hula O.S. (2013) Analiz faktoriv, shcho vplyvaiut na zminu rentabelnosti osnovnoho kapitalu, za metodom korporatsii «Diupon». [Analysis of the factors influencing the change in the return on equity capital, by the DuPont Corporation method]. The economy of the food industry. vol. 3, no. 19. pp. 21-23.

14. Semenova O. M., Sereda I. V. (2014) Rezervy pidvyshchennia rentabelnosti pidpryiemstva na osnovi faktornoho modeliuvannia [Reserves to increase the profitability of the enterprise on the basis of factor simulation]. Scientific herald of Poltava University of Economics and Trade. vol. 1, no. 63. pp. 162-167.

15. Sviridova S.S., Pozhar O.O. Otsinka faktoriv vplyvu na rentabelnist pidpryiemstva [Assessment of the factors affecting the profitability of the enterprise]. Young scientist. vol. 11, no. 14. pp. 93-96.

16. Farion V.Ya. Analitychna otsinka dilovoi aktyvnosti ta rentabelnosti pidpryiemstv [Analytical assessment of business activity and profitability of enterprises]. Innovative economy. vol. 10, no. 48. pp. 27-33. 
Chemchykalenko Ruslan

Candidate of Economic Sciences, Associate Professor, Senior Lecturer at Department of Finance and Credit Kharkiv Institute of Finance

Kyiv National University of Trade and Economics

Smoliakova Anna

Student

Kharkiv Institute of Finance

Kyiv National University of Trade and Economics

\section{WAYS TO IMPROVE THE MANAGEMENT EFFICIENCY OF ENTERPRISE PROFITABILITY (THE CASE OF TRADE ENTERPRISES)}

The purpose of the article. For a long time profit was considered by the enterprise to be its most important task. On the other hand, today the problems of managing profits and profitability of the enterprise supposedly go to the second plan, passing ahead the need to ensure the long-term existence of the enterprise, the maintenance and maintenance of competitive advantages, market capitalization of the enterprise. In fact, the achievement of any of the listed tasks is impossible without effective management not only the formation and distribution of profits, but also the profitability (profitability) of the enterprise as a whole or the implementation of its individual functions.

In this regard, the purpose of this article is to study the current state of managing the profitability of trade enterprises and identify possible ways to improve it.

Methodology. This study is based on the use of tools for correlation and regression analysis of statistical data of domestic enterprises in the wholesale and retail trade in relation to the impact of their financial status on the level of profitability of operating activities.

Results. In this article the modern state of profitability management of domestic enterprises is analyzed, including special attention paid to the enterprises of the sphere of wholesale and retail trade. It is established that the management of profitability of domestic enterprises of the trade sphere is gradually restored, but not without numerous problems. The information on possible directions of improvement of the management system of profitability of domestic business is generalized. It is established that the general problem of the system of research of factor influence on profitability of enterprise activity is insufficient estimation of force of such influence. Based on the use of correlation-regression analysis, a factor model for assessing the impact on operating profitability of trading enterprises of such factors as liquidity and solvency, financial sustainability and business activity is proposed. It was found that the strongest influence is on their level of liquidity and solvency. It is established that significant effect on the researched result indicator is also made by the ratio of receivables and payables and turnover of working capital of the enterprise.

However, it is worrying that, in accordance with the model for increasing the profitability of the operating activities of the enterprise, it is necessary to increase the amount of receivables in comparison with the amount of payables and, conversely, reduce the turnover of working capital. Regardless of the results of correlationregression analysis, in our opinion, from an economic point of view, the reduction of debt ratios would be more correct if growth of working capital turnover was increasing. Accordingly, we can state that this problem has the right to life, but requires a more thorough analysis using statistical data over a longer period, as well as with a diversification of factor indicators, including through the use of factors characterizing the influence of the environment on the enterprises of the sphere trade.

Value/originality. It is substantiated that consideration of the influence of all the above factors on the rendering of operational activity of domestic enterprises of the sphere of trade should contribute to increase of efficiency of this activity, but for the reasoned and effective use of them it is necessary to further check and extend both the horizon of analysis and the list of factors of influence. 